\title{
Valproik Asit Kullanımına Bağlı Liken Planus Olgusu
}

\author{
A Case of Lichen Planus Attached Use of Valproic Acid
}

\section{Fatma Şimşek}

Atatürk Üniversitesi Tip Fakültesi, Nöroloji Anabilimdal, Erzurum/Türkiye

Yazışma Adresi / Correspondence:

Fatma Şimşek

Atatürk Üniversitesi Tıp Fakültesi, Nöroloji Anabilimdalı, Erzurum/Türkiye

T: 905058347780 E-mail: klamaks@hotmail.com

Geliş Tarihi / Received : 06.02.2019 Kabul Tarihi / Accepted : 04.04.2019

Orcid No:

Fatma Şimşek https://orcid.org/0000-0003-1662-5534

Öz

Liken planus, kronik inflamatuar bir deri hastalığı olup koyu kahverengi veya mor-gri renkli maküllerle karakterizedir. Yapılan çalısmalar, patogenezde immünolojik mekanizmaların rol oynadığını gösterse de, etyoloji kesin olarak bilinmemektedir. Erzurum Atatürk Üniversitesi Tıp Fakültesi nöroloji polikliniğinde idiyopatik jeneralize epilepsi tanısı ile takip edilen ve valproik asit tedavisi başlandıktan bir buçuk yıl sonra ortaya çıkan döküntüleri histopatolojik inceleme sonrasında Liken planus tanısı alan vakayı sunuyoruz. Olgumuzda döküntüler sadece el-ayak bileklerinde lokalize olup yayılım göstermediği için tedavisi valproik asit ilaç dozunu azaltma ve lokal kortikosteroid kullanımı şeklinde düzenlendi. Takibinde likenoid reaksiyonlarda regresyon izlenmesi nedeni ile ilaç değişikliği yapılmadan tedavisine devam edildi. Literatürde valproik asit kullanımına sekonder liken planus vakası bildirilmemiştir.. ( Sakarya Tıp Dergisi 2019, 9(2):352-*355)

Anahtar Epilepsi; Valproik asit; Liken planus

Lichen planus, is a cronic and inflammatory cutaneous disease, characterized by dark brown or purple-gray macules. Although the studies made, have shown that immunological mechanisms play a role in the pathogenesis, the etiology is not known accurately. Erzurum Atatürk University Medical Faculty, in polyclinic of neurology, we present a case diagnosed with Lichen planus after histopathological and the rashes followed with the diagnosis of idiopathic generalized epilepsy and emerged after one, one and a half year, after the initation of valproic acid treatment. In our case, the rashes were localized only on the hand-feet ankles, and for not showing the spread, the treatment was regulated as the reduction of valproic acid drug dose and use of local corticosteroid. In the follow-up, due to the regression monitoring in lichenoid reactions, the treatment was continued without drug change. In literatüre, the case of lithera secondary Lichen planus have not been reported to use of valproic acid. (Sakarya Med J 2019, 9(2):352-355)

Keywords Epilepsy; Valproic acid; Lichen planus 


\section{GIIRIŞ}

Valproik asit epilepsi tedavisinde yaygın olarak kullanılan geniş spektrumlu antiepileptik ilaçlardandır. Deri reaksiyonları, antiepileptik ilaçların yaygın bir yan etkisidir ve tedavinin kesilmesinin ana nedenlerinden biridir. ${ }^{1,2} \mathrm{Ge}$ nellikle ilaca bağlı gelişen cilt döküntüleri ilacı bıraktıktan birkaç gün sonra azalarak kaybolmaya başlar ve çoğunlukla bu cilt döküntüleri yaygın ve makülopapüler özelliğe sahiptirler. Antiepileptik ilaçlarla ilişkili görülen en ciddi yan etkiler Stevens-Johnson sendromu, toksik epidermal nekroliz ve antikonvülzan aşırı duyarlılık sendromudur., ${ }^{3,4}$ Aromatik yapıya sahip olan (lamotrigin, okskarbazepin ve karbamazepin gibi) antiepileptik ilaçlarla tedavi sonrası döküntü oranları, aromatik yapıya sahip olmayan ilaçlarla (levetiresetam, valproik asit ve gabapentin gibi) tedavi edilen hastalardan daha yüksek oranda görülmektedir. Genel olarak ilaca bağlı cilt reaksiyonlarının kadınlarda daha sık olduğu bilinmektedir. ${ }^{5}$ Liken planus (LP) kronik inflamatuar mukokutanöz bir hastalıktır. Dünya popülasyonunun yaklaşık \%0.5-2’ sini etkilediği düşünülmektedir. ${ }^{6}$ Kadınlarda 2/3 oranında daha fazla görülmektedir. ${ }^{7}$ LP idiyopatik veya tümör, enfeksiyon, ilaç uygulanmasına sekonder ortaya çıkabilir. Etiyoloji tam olarak açıklanamamıştır. ${ }^{8}$ LP'de regresyon fazında papül rengi değişir ve kahverengiye döner. Beta blokerler, metildopa, penisilamin, kinidin, kinin, nadiren anjiyotensin dönüştürücü enzim inhibitörleri, sülfanilüre ajanları (glipizid, gliklazid, glimepirid gibi), karbamazepin, altın, lityum ve nonsteroidal antiinflamatuar ilaçlar LP gelişiminden sorumlu tutulmuştur. ${ }^{9}$

Yaklaşık on sekiz ay önce valproik asit tedavisi başlanmış olan ve son üç aydır yan etki olarak LP gelişen primer jeneralize epilepsi tanılı hastayı sunuyoruz. Hastadan bilgilendirilmiş onam formu alınmıştır.

\section{OLGU SUNUMU}

45 yaşında erkek hasta gece uykudayken tüm vücutta kasılma, dil ısırma ve idrar kaçırmanın olduğu jeneralize nöbet öyküsü ile nöroloji polikliniğine başvurdu. Şikayeti son bir ay içinde iki defa tekrarlamıştı. Hastanın 15 yıldır bazen bir bazen üç yıl arayla tekrarlayan, hepsi gece uykuda olan benzer şikayetleri vardı. Nörolojik muayenesi normaldi. Özgeçmiş ve soy geçmişinde özellik yoktu. Elektroensefalografi ve kranial manyetik rezonans görüntülemesi normaldi. Rutin tetkiklerde hemogram, biyokimya testleri normaldi. Mevcut bulgular ile idiyopatik jeneralize epilepsi tanısı konulan $80 \mathrm{~kg}$ ağırlığındaki hastaya valproik asit 1000 mg/gün başlandı. On sekiz aylık takip sonrasında nöbet tekrarı olmayan hasta son üç aydır el ve ayak bileklerinin iç yüzünde kaşıntı olması nedeni ile polikliniğimize başvurdu. El ve ayak bileklerinin medial yüzünde 3-5 mm çaplı, papüloskuamöz, kaşıntılı, pembe-mor renkte döküntüleri olduğu izlendi (Resim 1,2).
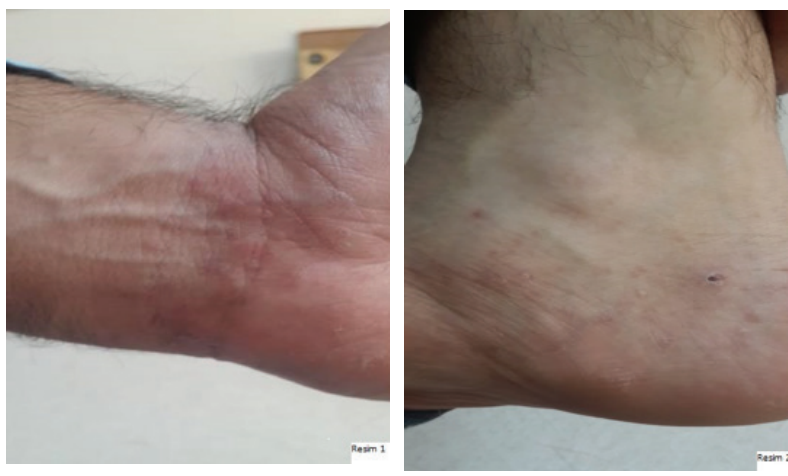

Resim 1,2: El ve ayak bileği medial yüzde papüloskuamöz, 3-5 mm büyüklüğünde, pembe-mor renkli döküntüler

Rutin hemogram, biyokimya tetkikleri, sedimentasyon, C-reaktif protein, vaskülit belirteçlerinde patoloji izlenmedi. Valproik asit dışında ilaç kullanımı yoktu. Lezyondan yapılan histopatolojik incelemede tüm epidermal tabakalara dağılmış nekrotik keratinositler görülmesi, dermal inflamatuar infiltratın derin yerleşimli olması likenoid ilaç reaksiyonunu desteklemekteydi. LP'de ise alt epidermal tabakalarda nekrotik keratinositler görülmekte ve dermal inflamatuar infiltrat yüzeyel yerleşim göstermektedir. Cildiye ile konsulte edilen hastaya ilaca sekonder liken planus tanısı ile lokal kortikosteroid başlandı. Antiepileptik ilaç başlandıktan sonra nöbet tekrarı olmayan hastanın ilaç dozu 750 mg/gün dozuna düşürüldü. İki ay sonra kontrolde lezyonlardan bir kısmının gerileyerek yerinde kah- 
verengi lekeler bıraktı̆̆g izlendi (Resim 3).

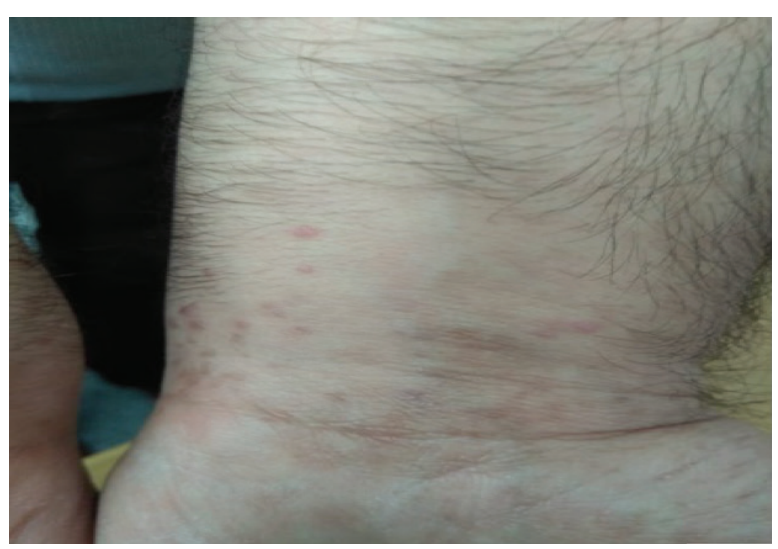

Resim 3: Valproik asit ilaç dozu azaltıldıktan ve lokal kortikosteroid kullanıldıktan 2 ay sonra döküntülerin bir kısmının gerileyerek yerini kahverengi lekelere bıraktığ izleniyor.

Lezyonlar sadece el ve ayak bileği medial yüzünde olup diğer bölgelere yayılım izlenmedi. İlaç değişikliği ile ilgili hastanın nöbet geçirme korkusu ve lezyonların lokalize bir bölgede olması nedeni ile ilaç değişikliği yapılmadan valproik asit ile $750 \mathrm{mg} /$ gün dozunda takibine devam edildi.

\section{TARTIŞMA}

Antiepileptik ilaç tedavisi sonrasında cilt döküntüsü sık görülen yan etkilerden biridir ve aromatik yapıya sahip olan antiepileptik ilaçlarda bu duruma daha sık rastlanmaktadır. Aromatik yapıya sahip olmayan valproik asitte döküntü yan etkisi diğer antiepileptik ilaçlara göre daha düşük oranda olup, literatürde valproik asit kullanımına bağlı bildirilen liken planus vakası olmadığı için olgumuzu sunmaya değer bulduk.

Karbamazepin kullanımı sonrasında değişik cilt döküntüleri görülebilmekle beraber uzun süreli ilaç kullanımı sonrasında likenoid erupsiyonlar nadirdir. ${ }^{10}$ Hajnsek S ve arkadaşları beş yıllık karbamazepin kullanımı olan ve beş yılın sonunda ortaya çıkan LP şeklinde döküntüleri olan yaşlı kadın olguyu bildirmişlerdir. ${ }^{11}$ İlacın başlatılması ve erüpsiyonun ortaya çıkışı arasındaki gecikme süresi aylardan bir yıla kadar veya daha fazla değişim gösterebilir ve bu durum ilacın türüne, dozajına, konak reaksiyonuna, ilaca önceki maruz kalmaya ve eş zamanlı ilaçlara bağlı olarak değişmektedir. ${ }^{12}$ LP'de oral tutulum sık olup ilaca bağlı likenoid reaksiyonda oral tutulum azdır. Genellikle ilaca bağlı cilt döküntüleri ilk birkaç ay için izlenmekte olup olgumuzda 15 ay valproik asit kullanımından sonra ortaya çıan likenoid döküntüler görüldü. Olgumuzda oral tutulum yoktu. Döküntüler fark edilip histopatolojik inceleme ile ilaca bağlı LP tanısı konulduktan sonra ilaç dozu 1000 mg/gün'den 750 mg/gün’e düşürüldü. Lokal kortikosteroid başlanan hastanın 2 ay sonra kontrolde regresyon fazıyla uyumlu olarak papül renginin kahverengiye döndüğü ve papüllerin azaldığı görüldü. Regresyon görülmesi, döküntülerin sadece el-ayak bileklerinin medial yüzüyle sınırlı olup yayılım göstermemesi ve nöbet tekrarı olmaması nedeni ile ilaç değişikliği düşünülmedi. Antiepileptik ilaçların düşük dozlarda da nöbetlere karşı koruyucu etkisinin olduğu bilinmektedir. Antiepileptik ilaç kullanımı sonrasında döküntü ortaya çıkması ve döküntülerin progresyon göstermesi halinde önerilen uygulama, ilaç değişikliği yapılmasıdır. Döküntülerde progresyon olması ve nöbet tekrarı durumunda ilaç değişikliği yapılması gerektiği hastaya anlatılarak bilgilendirme yapıldı.

$\mathrm{Bu}$ olgu bize nadiren de olsa valproik asit gibi aromatik yapıya sahip olmayan antiepiletiklerde de uzun süreli kullanım sonrasında bile LP gibi cilt döküntülerinin olabileceğini göstermektedir. 
Sakarya Tip Dergisi 2019;9(2):352-355

\section{Kaynaklar}

1. Aouam K, Bel Hadj Ali H, Youssef M, Chaabane A, Amri M, Boughattas N. A, et al. Carbamazepine-induced DRESS and HHV6 primary infection: The importance of skin tests. Epilepsia, 2008; 49(9): 1630-33.

2. Chadwick D, Safety and efficacy of vigabatrin and carbamazepine in newly diagnosed epilepsy: a multicentre randomised doubleblind study. Vigabatrin European Monotherapy Study Group. The Lancet, 1999; 354 (9172):13-19.

3. Pereira de Silva N, Piquioni P, Kochen S, Saidon P. Risk factors associated with DRESS syndrome produced by aromatic and non-aromatic antipiletic drugs. Eur J Clin Pharmacol, 2011; 67(5): 463-470.

4. Newell BD, Moinfar M, Mancini AJ, Nopper AJ. Retrospective analysis of 32 pediatric patients with anticonvulsant hypersensitivity syndrome (ACHSS) Pediatr Dermatol, 2009; 26(5):536-46.

5. Tran C, Knowles SR, Liu BA, Shear NH. Gender differences in adverse drug reactions. J Clin Pharmacol, 1998; 38(11): 1003-9.
6. Vincent $S D$, Fotos $P G$, Baker KA, Williams TP. Oral lichen planus: the clinical, historical, and therapeutic features of 100 cases. Oral Surg Oral Med Oral Pathol, 1990;70(2):165-71.

7. Mollaoglu N. Oral lichen planus: a review. Br J Oral Maxillofac Surg, 2000;38(4):370-77.

8. Basheer S, Shameena PM, Sudha S, Varma S, Vidyanath S, Varekar A. Expression of survivin and p53 in oral lichen planus, lichenoid reaction and lichenoid dysplasia: An immunohistochemical study. J Oral Maxillofac Pathol, 2017;21(3):456.

9. Thompson DF, Skaehill PA. Drug induced lichen planus Pharmacotherapy, 1994; 14(5): 561-71

10. Roberts DL, Marks R. Skin reactions to carbamazepine. Arch Dermatol, 1981;117(5):273-5. 11. Hajnsek S, Milavec-Puretic V, Nankovic S, Gadze ZP, Filipcic I, Kovac AB, et al. Lichen planus induced by carbamazepine: A case report. Epilepsye Behavior, 2012; 24(2): 269-71. 12. Brauer J, Votava HJ, Meehan S, Soter NA. Lichenoid drug eruption. Dermatol Online J 2009; 15(8):13 